\title{
Os jornais do PCB e a representação no Brasil da atuação soviética na Segunda Guerra
}

\section{Newspapers of the PCB and representation in Brazil of the Soviet role in World War II}

\author{
Moisés Wagner Franciscon ${ }^{1}$
}

Resumo: Ao utilizar as técnicas de análise de discurso sobre o texto jornalístico, o artigo aborda o impacto no Brasil do cinema bélico soviético sobre a Segunda Guerra. O contato com esse cinema se dava de várias formas. Os membros e simpatizantes do Partido Comunista Brasileiro detinham acesso a jornais diários ou semanais que, entre suas matérias, conferiam algum destaque ao cinema soviético. Os jornais replicavam a informação emitida pelas agências de notícias de Moscou, ou produziam seu próprio material. Os filmes concorriam (e as vezes venciam) em festivais internacionais. Em algumas ocasiões, foram exibidos oficialmente no próprio território brasileiro (durante os anos em que se procurou reatar as relações diplomáticas e comerciais entre o Brasil e a URSS). Esses jornais permitem apreender tanto a visão dos militantes sobre a Segunda Guerra quanto as variações dessa visão, provocadas pelas subsequentes fissuras no antigo monólito partidário. $\mathrm{O}$ que deixará marcas nas sinopses dos filmes ou nas colunas dedicadas às películas e sua produção, publicadas nos jornais Novos Rumos e Voz operária, entre 1949 e 1964.

Palavras-chave: Representação, mediação, PCB, Segunda Guerra.
Abstract: By using discourse analysis techniques on the journalistic text, the article addresses the impact on Brazil of the Soviet war film about World War II. The contact with this film was given in various ways. Members and supporters of the Brazilian Communist Party held access to daily or weekly newspapers, among its subjects, conferred some prominence to the Soviet cinema. Newspapers replicated information issued by news agencies in Moscow, or producing your own material. The films competed (and sometimes won) in international festivals. On some occasions, they were officially displayed in their own territory (during the years in which they sought to resume diplomatic and trade relations between Brazil and the USSR). These newspapers allow grasp both the vision of the militants on the Second War and the variations of this vision, caused by subsequent cracks in the old party monolith. What will leave marks on the synopses of the films or in columns devoted to films and their production, published in the newspaper Novos Rumos and Voz operária, between 1949 and 1964.

Keywords: Representation, mediation, PCB, World War II.

\footnotetext{
${ }^{1}$ Doutorando, UFPR. E-mail: mw.franciscon@ hotmail.com
} 


\section{INTRODUÇÃO}

O imaginário contemporâneo é fortemente embasado pelo cinema, pela representação que este faz do passado ${ }^{2}$. A produção fílmica se constitui numa das mais valiosas fontes para o século $\mathrm{XX}^{3}$. O cinema bélico soviético sobre a Segunda Guerra Mundial atingia não só militantes e simpatizantes do PCB, como também, ao menos nos anos 1960, um público maior e mais diversificado em cinemas, exposições e cineclubes ${ }^{4}$. Deve-se considerar o cinema soviético como um fator importante para a formação da imagem da atuação da URSS na guerra ${ }^{5}$, mesmo entre alguns brasileiros.

Ferro $^{6}$ pensa o cinema como uma chave para novas abordagens da história social. O filme permite captar características não-explícitas, os lapsos e conflitos da sociedade que o produziu, ou daquela que o exibe em seus telões. Além de captar as alterações de recepção de uma plateia de um dado filme segundo o tempo e o lugar.

Dênis de Moraes $^{7}$ afirma ter acontecido um enquadramento por parte do PCB dos anos 1940-50 da arte produzida por seus militantes enquadramento que encontrava seu espaço privilegiado nos jornais ligados ao partido (e na própria hierarquia e autoridade deste, segundo as opções daqueles que as reconheciam). Num primeiro momento os jornais do PCB eram os únicos mediadores entre seu público e o cinema bélico, seguindo o modelo comunicacional de reforço ideológico e de sectarismo político. Valim $^{8}$ indica como o circuito comunicacional se forma entre os diferentes

2 OLIVEIRA, Dennison. O cinema como fonte para a história. In: Fontes históricas: métodos e tipologias, 2008, Curitiba. III Evento de Extensão em Pesquisa Histórica, 2008. p. $1-12$.

3 BARROS, José D'Assunção. Cinema e história: considerações sobre os usos historiográficos das fontes fílmicas. Comunicação \& Sociedade, São Paulo, v.32, n.55, 2011. p. 175-202.

${ }^{4}$ Como os dois jornais do PCB acusam ao longo do tempo, as exibições eram promovidas por cinemas particulares no Rio de Janeiro, cineclubes de estudantes secundaristas e universitários, eventos direcionados para um público amplo e com entrada franca, patrocinados por entidades públicas nacionais e estrangeiras e grupos de interesses.

${ }_{5}^{5}$ OLIVEIRA, Dennison. O cinema e a Segunda Guerra Mundial no século XXI. In: VIII Encontro Nacional de História da Mídia, 2011, Guarapuava. $8^{\circ}$ Encontro Nacional de História da Mídia-Rede Alcar. Guarapuava: Ed. da UNICENTRO, 2011. v. 1. p. 1-1.

${ }^{6}$ FERRO, Marc. Cinema e história. Rio de Janeiro: Paz e Terra, 1992.

${ }^{7}$ MORAES, Dênis. O imaginário vigiado: a imprensa comunista e o realismo socialista no Brasil. Rio de Janeiro: José Olympio, 1994.

8 VALIM, Alexandre Busko. Imagens vigiadas: uma História Social do Cinema no alvorecer da Guerra Fria - 1945-1954. Niterói, 2006. p.324. Tese de Doutorado. UFF. Área de Concentração: Cultura e Sociedade. 
segmentos da mídia: jornal, revistas, cinema, num ciclo contínuo de reforço de imagens, representações. O que pode ser verificado em jornais como Voz operária.

Foram selecionados dois jornais, Voz operária (1949-1959) e Novos Rumos (1959-1964). Ambos podem ser vistos como apenas um jornal, já que passou por uma reestruturação, ganhou um novo nome, porém manteve parte dos produtores e a mesma relação especial com o partido.

No Brasil, quando o circuito comunicacional tornou-se completo, ou ao menos acessível para um público amplo, o corpo do imaginário sobre o desempenho da URSS e de seus líderes na Segunda Guerra passou por um processo de revisão dentro do partido, do mundo acadêmico, da sociedade e da cinematografia, num processo conhecido como Desgelo 9 . Ao invés de reforçar a hegemonia de um segmento dentro do PCB, contribuiu para a sua queda e a ascensão e a consolidação de uma nova facção e de um novo programa de partido. No entanto a transição não foi simples. Foi demorada, tensa, com tentativas frustradas de acomodação e incertezas sobre os resultados e quem seriam os vencedores. O que pode ser captado nas sinopses dos filmes bélicos soviéticos apresentadas nos jornais comunistas.

Nesse sentido, informações valiosas sobre atitudes e tendências difundidas, até porque os públicos escolhem os filmes pelas representações em revistas, televisão, jornais, conversas e outros contatos sociais. Desse modo, outros meios de comunicação devem ser estudados em conjunto com esses filmes, visto que sua utilização como discurso social sobre os filmes pode enriquecer bastante a análise.

$\mathrm{Se}$ os indivíduos podem produzir seus próprios significados com os textos veiculados pela mídia, é porque a hegemonia é negociada, renegociada e vulnerável a ataques e à subversão, em uma relação em que o próprio cinema, contraditoriamente, oferece recursos que os indivíduos podem acatar ou rejeitar na

\footnotetext{
${ }^{9}$ O Desgelo durou de 1956, com o XX Congresso do Partido Comunista da União Soviética, até 1964, com o afastamento do sucessor de Stalin, Nikita Kruschev (1953-1964). A desestalinização encontrou forte oposição vinda de facções políticas dentro do PCUS, bem como de setores da sociedade alinhadas com o stalinismo (que ganhou legitimação popular com a vitória na Segunda Guerra e a política de diminuição dos preços dos produtos de consumo popular no fim da década de 1940). Os grupos que sucederam aos reformadores não retroagiram para além do restabelecimento do sistema econômico centralizado. BROWN, Archie. The Rise and Fall of Communism. Londres: HarperCollins, 2010.
} 
formação de suas identidades, em oposição aos modelos dominantes.

$\mathrm{O}$ estudo do que denomino de "circuito comunicacional" requer, assim, uma análise da produção e da economia política dos textos, bem como da interpretação textual, assim como o exame da recepção por parte do público e de seu uso por diferentes atores sociais ${ }^{10}$.

Maingueneau ${ }^{11}$ apresenta a análise do discurso como a técnica que permite captar elementos e posicionamentos ideológicos ocultos no texto, ler entrelinhas, desde que em uma fonte que delimita e cristaliza um discurso ou formação discursiva. O que é o caso da imprensa comunista. Também lembra da relação entre a linguística, as escolhas feitas na produção do texto, a construção e a transformação das relações entre interlocutores, seus enunciados e seus referentes. Pode-se assim perceber o papel dos jornais do PCB na tentativa de constituição de um círculo comunicacional sobre a história do comunismo, que possuía como auge a recente vitória na Segunda Guerra, que anunciava a superioridade do sistema e a derrota vindoura do capitalismo. Tratava-se de reificar as representações caras aos seus membros, como a unidade, a coragem, a luta, a fé no futuro, o desprendimento, a liderança, etc.

A crítica feita por Flamarion Cardoso ${ }^{12}$ à noção de representação de Chartier (de que não dá a devida atenção aos fatores materiais, eclipsados pelo cultural) é válida. Apesar de ancorar seu trabalho na sociologia de Bourdieu, Chartier se distancia do mesmo ao afirmar que a representação se baseia em "códigos e não das classes ou grupos"13. A persuasão das representações e o poder que impõe tem sua maior validação pelas relações sociais e não pelos discursos e representações em si mesmos. Assim, representação social são os "saberes partilhados, crenças, sistemas de pensamento gerados em interação, socialmente. A representação social aparece como um tertius entre sujeito e objeto, mediatizando a relação entre

10 VALIM, Alexandre Busko. Imagens vigiadas: uma História Social do Cinema no alvorecer da Guerra Fria - 1945-1954. Niterói, 2006. p.324. Tese de Doutorado. UFF. Área de Concentração: Cultura e Sociedade.p.39.

11 MAINGUENEAU, Dominique. Novas tendências em análise do discurso. Campinas: Pontes, 1989.

12 CARDOSO, Ciro Flamarion; MALERBA, Jurandir (Orgs). Representações: contribuição a um debate transdisciplinar. Campinas: Papirus, 2000.

${ }^{13}$ CHARTIER, Roger. A ordem dos livros. Brasília: EdUnb, 1999.p.15-16. 
eles" ${ }^{14}$. A criação e os desenvolvimentos subsequentes da representação do papel soviético na Segunda Guerra entre os militantes do PCB se dá pelo jogo de interesse entre as facções políticas e as experiências dos afiliados como a possibilidade de assistir a um filme soviético que contradiz imagens cristalizadas.

Com a crescente cisão entre facções reformadoras e conservadoras no Partido Comunista Brasileiro ${ }^{15}$ e a crise entre os países do bloco socialista $^{16}$ a reforçar esse processo, os jornais do PCB viam a debandada de antigos e destacados membros do partido que eram inclusive seus jornalistas, colunistas e editores, como João Amazonas, Maurício Grabois e Carlos Danieli. Em 1958 o programa foi alterado e em 1960 realizou-se seu V Congresso ${ }^{17}$. O partido abandonou o sectarismo pela linha de frente única em 1958 e uma agenda de "participação positiva" e de luta por sua saída da semilegalidade $^{18}$.

A partir de 1952, o jornal [Voz operária] conheceu mudanças, sobretudo no sentido de atrair maior público: fotografias, caricaturas e notícias de interesse

14 CARDOSO, Ciro Flamarion. O uso, em história, da noção de representações sociais desenvolvida na psicologia social. Psicologia e Saber Social, Rio de Janeiro, v.01, n.01, 2012, p. 40-52.p.42.

${ }^{15}$ Por trás do aparente monólito, os partidos comunistas eram crivados por facções. Apenas no PCUS existiam grupos tão variados quanto stalinistas, comunistas idealistas, nacionalistas, socialdemocratas e liberais (BROWN, Archie. The Rise and Fall of Communism. Londres: HarperCollins, 2010, p. 415), que se aliavam ou entravam em conflito. O Partido Comunista Afegão possuía cisões tão profundas e inconciliáveis que gerou uma guerra civil entre os seus membros antes mesmo da intervenção soviética em 1979. Uma vez que percebiam Moscou como modelo a seguir, a facção no poder na URSS conseguia angariar simpatias nas suas homólogas nos demais partidos comunistas mundo afora, que acabavam por se consolidar na própria hierarquia local.

${ }^{16}$ Nem sempre era bem sucedida essa relação da facção líder em Moscou facilitar o caminho para sua equivalente dentro do partido comunista em outros países. A China não acompanhou a substituição dos stalinistas por reformadores seguidores de Kruschev; que pregavam a coexistência pacífica com o mundo capitalista (ao menos até o presidente americano Richard Nixon firmar uma aliança informal antissoviética com Mao Tsé-tung em 1972), a chegada pacífica ao poder por meio eleitoral, a inserção de mecanismos de mercado no sistema econômico comunista. A crise com a China, iniciada após os alertas de Kruschev contra a coletivização da agricultura chinesa e o fim do repasse de tecnologia nuclear soviética à China, na virada dos anos 1950-1960, foi precedida pela passagem da Iugoslávia de Tito para o Bloco dos Países Não-Alinhados e sucedido por novas adesões à rebeldia ideológica chinesa, como a Albânia de Hoxda e o Camboja de Pol Pot. Algumas facções preferiram seguir Pequim, como a que se separou do PCB e criou o PC do B, em 1963.

${ }^{17}$ CARONE, Edgard. O PCB (1943-1964). São Paulo: DIFEL. 1982.p.15-27.

${ }^{18}$ MARÇAL BRANDÃO, Gildo. Esquerda positiva: as duas almas do Partido Comunista 1920-1964. São Paulo: Hucitec. 1997. 
nacional - e não apenas partidário -, bem como sessões dedicadas ao cinema, às artes, à literatura e ao teatro. Uma novidade, sem dúvida. Não tardou, porém, para surgirem as primeiras tensões entre os jornalistas e a direção partidária.

O Comitê Central acusava os jornalistas de adotarem linha "reformista". A tensão alcançou o apogeu com a divulgação do "relatório Kruchtev", em fevereiro de 1956. Desconhecendo o Comitê Central do partido, os jornalistas abriram as páginas de Voz operária e Imprensa Popular para debater as graves denúncias contidas no relatório. A autonomia do grupo, renovador e antiestalinista, que dirigia os jornais, tornou-se intolerável para o "núcleo dirigente"19.

Os redatores foram expulsos. Em maio de 1957 Osvaldo Pereira, Agildo Barata, Aidano do Couto Ferraz, deixaram o jornal e o partido. Voz operária foi fechado em 1959. Reabriu no mesmo ano como Novos rumos, simbolizando a nova linha do PCB. De mensal, passou a ser semanal. Possuía filiais em Minas Gerais, São Paulo e Paraná. A tiragem chegou a 60 mil exemplares. Seus colaboradores eram Astrojildo Pereira, Carlos Marighella, Giocondo Dias, J. Câmara Ferreira, João Massena Melo, Leandro Konder, Hércules Correa, Rui Facó e Sinval Palmeira. Fechado com o Golpe de 1964, tornou-se a chamar Voz operária, agora mimeografado ${ }^{20}$.

\section{OS ANOS DA ORTODOXIA}

Para os jornais comunistas do fim dos anos 40 e início dos 50, o cinema soviético era um retrato fiel do passado. Uma aula de realidade histórica. $\mathrm{O}$ que era de se esperar diante das concepções do realismo socialista de que a arte deve refletir a realidade. Quando a imprensa tradicional faz afirmações que vão ao encontro da imprensa comunista, estas acabaram replicadas em Voz operária. Como é o caso do filme sobre o compositor ucraniano Modesto Moussorgsky, exibido na Argentina. O La Prensa e o La Nacion "assinalam a veracidade histórica do filme e elogiam o desempenho dos artistas e músicos, pondo em relevo o alto nível da arte

\footnotetext{
${ }^{19}$ FERREIRA, Jorge. Novos rumos: jornal do Partido Comunista Brasileiro. Locus: revista de História, Juiz de Fora, v.19, n.02, 2013, p. 205-224.p. 207.

${ }^{20}$ FERREIRA, Jorge. Novos Rumos: jornal do Partido Comunista Brasileiro. Locus: revista de história, Juiz de Fora, v.19, n.02, 2013, p. 205-224.p.208-212.
} 
cinematográfica soviética" ${ }^{21}$. Apesar de ser uma película sobre um compositor clássico do século XIX, como filme histórico, compartilha a mesma imagem nacionalista e de factualismo histórico do cinema bélico. Um filme de fantasia (gênero comum e de liberação eficaz diante da censura stalinista), baseado no folclore russo e na obra musical de RimskyKorsakov, Sadko, 1952, do diretor Aleksandr Ptushko, é igualmente citado como exemplo da primazia soviética no cinema mundial: "Também apresentado no Festival de Veneza, o filme soviético "Sadko" foi um grande sucesso na Itália, sendo saudado unanimemente pela crítica italiana como um grande filme ${ }^{22}$.

$\mathrm{O}$ entrelaçamento de arte e realidade, e a visão dessa realidade como a do heroísmo modelar e engajamento político, a resistência popular ao invasor fascista, podem ser percebidos nos comentários de Voz operária sobre o filme Molodaya Gvardiya, 1948, de Serguei Gerasimov: "Dimitri Shostakovitch está escrevendo a música para um filme baseado na famosa novela de Alexander Fadeev, 'A jovem guarda', que focaliza o heroísmo dos guerrilheiros soviéticos durante a ocupação alemã da Ucrânia"23. Literatura e música clássica se envolvem na produção fílmica.

Essa visão do cinema soviético como arte e descrição vívida da realidade e do passado, bem como detentor mundial da vanguarda tecnológica ${ }^{24}$ e visual na área, é ressaltada com a matéria "Por que não podemos assistir a estes filmes?", publicada sete meses após a morte de Stalin:

O cinema soviético é o melhor cinema do mundo. Este fato indiscutível é reconhecido em todos os países pelo

\footnotetext{
${ }^{21}$ Voz operária, p.2, 19/7/1952.

${ }^{22}$ Voz operária, p.9, 31/10/1953.

${ }^{23}$ Voz operária, p.6, 26/2/1949.

${ }^{24}$ Como foi o caso da reportagem de Voz operária sobre o cinema 3D na URSS, chamado de cinema em relevo pelo jornal Novos Rumos, anos depois (Voz operária, p.11, 1/11/1952). Um correspondente que permaneceu dois anos em Moscou comparou os avanços técnicos ocidentais com os técnicos e artísticos da URSS. O jornal reproduz, mesmo em 1959, o discurso stalinista. $\mathrm{O}$ ocidente avança na técnica mas se esvazia no conteúdo. Também se relativiza avanços como o cinemascópio e o cinerama (a primeira tentativa de criar um longa-metragem em 3D data ainda de 1922. A baixa qualidade impeliu a criação do sistema cinemascope em 1953: filmado e projetado com o auxílio de três câmeras, reproduzido numa tela extensacurva - ou espelho mágico. A curvatura da tela e o som estereofônico disperso pela sala provocavam a sensação de imersão nas imagens) em comparação com o cinema em relevo ou 3D soviético. "Através do progresso técnico, a forma ficou mais esmaltada, mais rica em recursos. Mas que se fez para manter intacto e vivo o conteúdo?" (Novos Rumos, p.9, 8-14/5/1959).
} 
público que tem a oportunidade de assistir aos filtros do País do Socialismo, como pelos críticos e cineastas honestos de todas as tendências.

Em lugar dos estúpidos temas do cinema americano, em que o crime, o gangsterismo, a exaltação dos mais baixos instintos, o ódio à cultua e, em primeiro lugar a propaganda de guerra são os assuntos preferidos, o cinema soviético é um poderoso instrumento da educação das massas. Os mais variados temas têm dado lugar a filmes maravilhosos que apaixonam os espectadores em toda parte onde já foram projetados. Os filmes tratam de acontecimentos históricos como "Suvorov" e "Alexandre Nevsky" ou os mais recentes "A queda de Berlim" e "A Batalha de Stalingrado", outros focalizam a vida de grandes vultos científicos da humanidade como "Mitchurin" ou "Pavlov", ou então o gigantesco trabalho do povo soviético para a consideração do socialismo e agora do comunismo, filmes esses que abrem novos horizontes à compreensão dos que os assistem, como "A Terra", "A volta de Alexandre Bortnikov", "Longe de Moscou" e muitos outros. Em todos os gêneros o cinema soviético tem produzido os maiores filmes que já foram dados à humanidade conhecer, porque são filmes ricos de um conteúdo profundo e humano, que ensinam a viver e a lutar, além de serem realizados num nível técnico e artístico inigualado ${ }^{25}$.

O cinema americano é criticado por seu militarismo. Como o jornal poderia tratar das películas bélicas soviéticas? Filmes como Padeniye Berlina (1949, de Chiaureli) e Stalingradskaya Bitva (1948, de Petrov) não são considerados filmes de guerra e sim como filmes históricos (que é o mesmo caso do filme Suvorov, 1940, de Pudovkin, ambientado nas campanhas do famoso marechal russo nos Alpes durante as guerras napoleônicas). O que resolve o paradoxo de um cinema bélico anti-belicista, já que oposto ao americano. Adiante, o jornal critica o fato do grande público brasileiro estar privado de assistir a esses filmes nas salas de cinema. O que já fora mencionado anos antes, durante o III Festival internacional do RJ e a proibição de filmes soviéticos pelo governo Dutra ${ }^{26}$.

Por que esses filmes não são exibidos no Brasil?

${ }^{25}$ Voz operária, p.9, 31/10/1953.

${ }^{26}$ Voz operária, p.13, 25/11/1950. 
Simplesmente porque não existindo relações entre o Brasil e a União Soviética os monopólios americanos e o reacionarismo do governo de Vargas proíbem sua projeção. Como se vê, além de ser prejudicado em seu nível de vida com a ausência de relações comerciais com a URSS, nosso povo está também privado de tomar contato com as grandes realizações artísticas do cinema soviético, está privado de tomar conhecimento de um dos maiores patrimônios culturais da humanidade e de elevar-se com isso.

Para terminar com essa situação injustificável, todos os brasileiros exigem do governo que reate relações diplomáticas e comerciais com a U.R.S.S., o que trará imensos benefícios ao nosso povo ${ }^{27}$.

Realmente ninguém no Brasil possuía acesso a esses filmes? O Kremlin produzia cópias dos filmes soviéticos no período stalinista e os enviavam para o exterior até pela finalidade de formação política. Circulavam legalmente e com apoio dos regimes socialistas recém instalados no Leste Europeu e Extremo Oriente. Se o governo brasileiro não mantinha relações com a URSS, não chegou a cortar os laços com o da Polônia. Latas com filmes poloneses eram enviados legalmente para o Brasil e exibidos em salas de cinema, como lembra a nota de Voz operária que relata a exibição de um filme bélico sobre a atuação soviética e do Exército Popular Polonês. No dia 22 de agosto, Festa Nacional da Polônia, foi "exibido no auditório da Associação Brasileira de Imprensa" "um filme sobre as lutas pela libertação de Varsóvia”, "à qual compareceram perto de duas mil pessoas" 28 .

\section{CRISE E REVISÃO}

Com o discurso secreto $^{29}$ do premiê Nikita Kruschev no XX Congresso do PCUS, a revisão histórica tomou conta das obras cinematográficas sobre a Segunda Guerra. Os editores e jornalistas dos jornais comunistas no Brasil ficaram diante do difícil dilema de informar

\footnotetext{
${ }^{27}$ Voz operária, p.9, 31/10/1953.

${ }^{28}$ Voz operária, p.5, 26/7/1952.

${ }^{29}$ Que, de secreto, foi muito pouco, ao menos dentro da União Soviética, como lembram os irmãos Medvedev (MEDVEDEV, Z.; MEDVEDEV, R. Um Stalin desconhecido. Rio de Janeiro: Record, 2006). Cópias resumidas foram impressas pelo partido e distribuídas para que fossem lidas durante os horários reservados para as reuniões em fábricas, escolas, repartições públicas, por toda a URSS nos dias seguintes à fala do premiê.
} 
sobre esses filmes em meio as transformações e mudanças na hierarquia do partido, tanto na União Soviética quanto no Brasil, e as crescentes tensões entre facções ortodoxas ou stalinistas e as renovadoras ou revisionistas e desnaturalizadoras. Como a Grande Guerra Patriótica deveria ser vista no cinema? As certezas da primeira metade e meados da década de 1950 foram substituídas por silêncios e incertezas.

É o caso do primeiro filme soviético que revisou a representação da guerra, Letyat Zhuravli, de 1957, de Mikhail Kalatozov. Inicialmente traduzido pelo jornal Novos Rumos como "Quando passam as Cegonhas", ganhou o prêmio de Cannes, "sob os mais calorosos aplausos da crítica internacional" - mas o jornal não oferece nenhum pormenor do filme, por mais reconhecido que tenha sido no exterior e no interior da $\mathrm{URSS}^{30}$. Um contraste notável com, por exemplo, a forma pela qual $A$ volta de Vasili Bortinikov, de 1953, do diretor Pudovkin, foi descrito anos antes por Voz operária, mesmo sem ganhar qualquer prêmio no Festival de Veneza ${ }^{31}$. No ano seguinte, recebe novamente um comentário passageiro: "Quando voam as cegonhas era um candidato a altura para a Palma de Cannes" 32 . O mesmo aconteceu com Balada do soldado, 1959, de Grigori Chukhrai, premiado no Festival de Filmes dos Trabalhadores, na Tchecoslováquia ${ }^{33}$.

O clima de aproximação econômica, social e política com o ocidente promovido pelo novo premiê acaba ressaltado com o filme NormandieNiemen, 1960, de Dréville e Viatich-Berejnykh. O jornal dispensa uma coluna para evidenciar os novos laços da URSS, no caso, com o cinema francês $^{34}$. Novamente um filme revisionista recebe atenção na URSS e no exterior. Novamente o jornal procura dissipar seu conteúdo crítico.

\footnotetext{
${ }^{30}$ Novos rumos, p.1, 28/6/1958.

31 "Esta cena é do magnífico filme de Pudovkin "A volta de Vasili Bortnikov". No Festival de Veneza, devido ao julgamento guiado pela discriminação política de juízes a soldo de Hollywood, não obteve nenhum prêmio. Mas, além de uma obra-prima, esse filme de Pudovkin é uma lição de moral, de serenidade e de confiança. São ai vividos de forma apaixonante a vida coletiva dos colcoses os problemas de sua direção, da formação dos quadros agrícolas das relações entre o P.C. e a população soviética" (Voz operária, p.9, $31 / 10 / 1953)$.

${ }^{32}$ Novos rumos, p.9, 10-16/4/1959.

${ }^{33}$ Novos rumos, p.5, 16-22/9/1960.

34 "CO-PRODUÇÃO: Iniciada a primeira co-produção franco-soviética que revive uma grande página da história da última guerra — a atuação dos pilotos de caça franceses alistados nas Forças Francesas Livres que participaram dos combates no fronte de batalha russo." "O título do filme é «Normandie-Niemen» e sua história foi escrita em colaboração por Charles Spaak, Elza Triolet e Constantin Simonov, sendo a direção de Jean Dréville. No elenco estão Mare Cassot, Giani Esposito, Gérard Buhr, Georges Riviere, André Ormansky e outros. As filmagens devem durar cinco meses." (Novos rumos, p.9, 10-16/4/1959).
} 
Dirigido e interpretado por um dos mais famosos atores soviéticos (Serguei Bondartchuk), «O Destino de Um Homem» arrebatou o principal prêmio da competição [o Festival Cinematográfico de Moscou, de âmbito internacional]. A história dramática de um homem que vê a guerra levar ao seu lar e à sua família toda sorte de sofrimentos, comoveu pelo seu impressionante realismo. Bondartchuk, estreando como diretor, transpôs com fidelidade o romance de Mikhail Cholokov o que lhe valeu os mais entusiásticos aplausos $^{35}$.

Apenas no ano seguinte o cinema bélico revisionista receberia maior atenção ${ }^{36}$. O que ocorre com a reportagem "As cegonhas trazem esperanças - Quando voam as cegonhas", um suplemento especial de duas páginas no fim do jornal. Ilustrações recobrem a maior parte do espaço da matéria.

A imagem de Verônica, flores na mão, a espera de Boris quando a guerra termina, acompanho o espectador, e prolongando as emoções acumuladas durante a exibição do filme.

\footnotetext{
${ }^{35}$ Novos Rumos, p.4, 28/9/1959.

${ }^{36} \mathrm{O}$ cinema bélico revisionista se opõe às películas que reproduzem o discurso oficial. Revira o que é visto como verdade por seus pares. Traz à tona discursos esquecidos, rejeitados ou apagados. É crítico por definição. Podem ser laudatórios, desde que de uma personalidade ou evento antes malquistos ou considerados tabu. Os primeiros filmes revisionistas aparecem na URSS com o relatório antistalinista de Kruschev, em 1956. No entanto, as pressões por liberdade artística floresceram nos sindicatos e outros órgãos soviéticos imediatamente após a morte de Stalin, em 1953. Ehrenburg publicou o seu romance $O$ degelo, no qual traça um chefe de empresa despótico com os empregados, uma caricatura de Stalin, em 1954. CARDOSO, Maria Luísa L. de O. F. História da Arte e Guerra Fria. Lisboa, 2012. p.376. Tese de Doutorado. Universidade Nova de Lisboa. Área de Concentração: História da Arte Contemporânea. Nos Estados Unidos, são ligeiramente mais antigos. Cidadão Kane, 1940, de Orson Wells, já levantava dúvidas sobre as reais causas da Guerra Hispano-Americana de 1898. Especificamente bélico, The steel helmet, 1951, de Samuel Fuller, produzido em meio à Guerra da Coreia, se mostrava os nortecoreanos como selvagens, também lembrava o racismo no exército americano ou sugeria crimes de guerra. As pontes de Toko-Ri, de 1954, de Mark Robson, apresentava a Guerra da Coreia como carnagem sem sentido. Se o conflito entre doves (pombas, pacifistas progressistas ou de centro-esquerda) e hawks (falcões, militaristas conservadores) que dividia a sociedade americana nos anos 1950-70 era aberto (CAPELATO, Maria Helena. História e cinema. São Paulo: Alameda, 2011, p. 310), as fissuras soviéticas eram menos claras.
} 
Os noivos costumavam encontrar-se pela madrugada, ambiente lírico onde construíam seus sonhos matrimoniais, esperança de uma vida tranquila num mundo de trabalho e paz.

A violência nazista interrompe bruscamente as fantasias dos jovens, e Boris alista-se como voluntário no Exército Vermelho, partindo para o campo de batalha.

Nas peripécias do combate, uma bala atinge o soldado Boris. No meio do bosque, em delírio, o moribundo vê o término da guerra, entra na casa de Verônica, que o recebe em encantador vestido de noiva, prepara-se o casamento... as imagens começam a confundir-se, as bétulas, em ciranda louca, erguem-se e levam para o infinito toda a vida que aguardava o jovem.

Na Sibéria, onde também participa do esforço em que está empenhado o país, Verônica tem seu pensamento voltado para o longínquo lugar onde supõe estar o noivo. No hospital, enfermeira, tem uma vida atribulada, cuidando dos feridos e buscando repelir a ideia de viver com Mark, primo de Boris que a seduzira.

No Dia da Vitória, Verônica vai à estação receber os heróis que regressam. Encontra um companheiro de Boris, Stepan, cujos olhos transmitem à jovem a tragédia, enquanto em volta rostos alegres transmitem a felicidade dos que se reencontram.

As flores são repartidas entre os veteranos que escaparam. As flores colhidas por Verônica para Boris.

As cegonhas, tal como no princípio do filme, sobrevoam a cidade. Trazem a esperanço de uma vida nova que começa. A moça, de entre as lágrimas, esboça um débil sorriso, o sorriso da vida a refazer ${ }^{37}$.

Um jovem diretor reuniu jovens atores e procurou uma história de amor e de esperança. As luzes, a câmera, e «Quando voam as cegonhas» se transformou numa das mais belas realizações do cinema. Tatiana Samóilova, Alexei Batalov, A. Shvorin e o diretor M. Kalatósov ganharam fama universal recebendo a «Palma de Ouro» no Festival de Cannes ${ }^{38}$.

${ }^{37}$ Novos rumos, p.19. 3-9/6/1960.

${ }^{38}$ Novos rumos, p.20. 3-9/6/1960. 
O filme recebe matérias em três edições seguidas. A constante insistência no assunto é desnuviada em seguida. Tratava-se de uma preparação do público do jornal, da militância e simpatizantes comunistas, para a estreia nos cinemas cariocas do filme de Kalatozov.

AS CEGONHAS VÊM AÍ - Trazendo a beleza exótica de Tatiana Samóilova, estreará no próximo dia 27 no Rio de Janeiro o filme soviético «Quando voam as cegonhas», realização de M. Kalatazov, premiada com a «Palma de Ouro», o maior laurel do Festival de Cannes. Tatiana, na foto, tendo ao lado a extravagante Jane Mansfield, ganhou fama e popularidade em todo o mundo, graças a sua beleza e ao seu talento.

O filme será apresentado no Rio em [?] circuito que alcançará cinemas do Centro, da Zona Norte e da Zona $\mathrm{Sul}^{39}$.

Com a coexistência pacífica, apesar da manutenção do afastamento comercial e diplomático do Brasil com a URSS ${ }^{40}$, os filmes soviéticos premiados em festivais internacionais recebem a permissão para entrar no circuito de exibição nacional.

Os sinais de mudança no sistema soviético e sua representação são mais visíveis na imagem ilustrativa de Tatiana Samóilova em um drinque com champanhe com a atriz americana Jane Mansfield do que no texto das sucessivas reportagens do jornal. A rigidez revolucionária dá espaço para o consumo na Riviera Francesa, durante o Festival de Cannes. A desestalinização avança com as reformas do premiê Kruschev.

Ao contrário do que aponta o jornal, Boris não alista-se como voluntário. Pelo contrário, prefere a longa esperada da convocação. Diz ter

\footnotetext{
${ }^{39}$ Novos rumos, p.6. 24-30/6/1960.

${ }^{40}$ O governo Dutra (1945-50), ansioso pelo alinhamento com os EUA com a eclosão da Guerra Fria, rompeu relações com a URSS em outubro de 1947. O PCB foi posto na ilegalidade poucos meses antes. Tratava-se tanto de política doméstica, com a supressão de um opositor interno incomodo que havia crescido muito nas eleições de 1945 (com a acusação de financiamento externo pelo "ouro de Moscou"), como prova formal do abandono da linha diplomática autônoma de Vargas. Ganhava-se assim a confiança americana. Juscelino Kubitschek iniciou a reaproximação, em 1959, concretizada por Jânio Quadros em 1961. A exibição dos filmes soviéticos serviu a ambos os governos, ansiosos por negociarem commodities brasileiras por maquinas soviéticas, como iniciativa de relações públicas contra a impopularidade da reaproximação - segundo pesquisa encomendada pelo governo americano. MOTTA, Rodrigo Patto Sá. O perigo é vermelho e vem de fora. Locus: revista de história, Juiz de Fora, v.13, n.02, 2007, p. 227-246.p.239.
} 
medo da morte. Absorto pelo medo, é incapaz de compartilhar do entusiasmo do desfile de despedida ao som da marcha militar Adeus à Slavianka ou de perceber que pisa as flores lançadas por Verônica. O jornal se cala sobre o motivo da ausência de Boris e a presença de Mark - o pai deste possuía os vínculos políticos necessários para salvaguardar o filho da convocação, que recaia sobre os demais com a mesma idade. Verônica não parte para a Sibéria para reforçar o esforço de guerra, mas sim por seu pai ter sido morto e sua casa destruída durante um bombardeiro à inexpugnável Moscou da versão histórica stalinista.

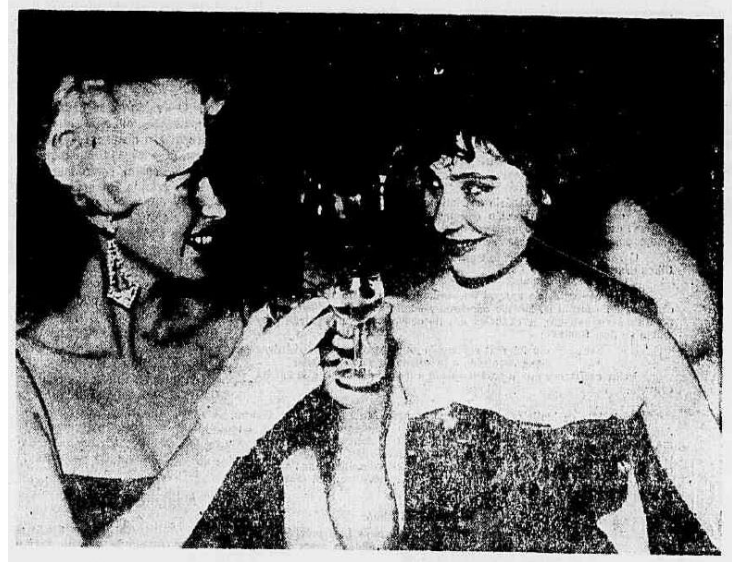

A Coconas Mem

Samóilova e Manssinióla nāo são nada perto de Renata Francischini

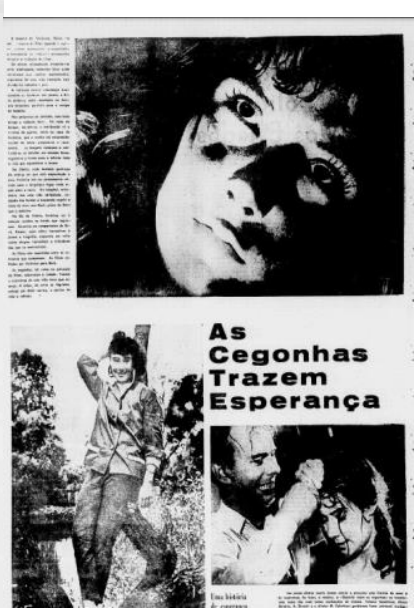

Figura 1 - Quando voam as cegonhas nas páginas de Novos Rumos. Fonte: Novos rumos, p.6. 24-30/6/1960; Novos Rumos, p.20. 3-9/6/1960.

Covardia, apatia, conformismo, corrupção e favorecimento não eram compatíveis com a representação tradicional da Grande Guerra Patriótica veicula na mídia comunista brasileira. A sinopse acaba reescrita sob as normas e impressões ainda correntes entre os ortodoxos. No mês seguinte, e com os filmes ainda em cartaz nos cinemas cariocas, o correspondente Gennyson Azevedo tece novos comentários:

Um dos acontecimentos do ano cinematográfico é, sem sombra de dúvida, a estreia de «Quando Voam as Cegonhas» (Lietiat Juravii). A revelação da grande atriz que é Tatiana Samoilova já bastaria para atrair as atenções gerais mas, «Quando Voam as Cegonhas» tem a marca do grande cinema, das obras que ficam incorporadas ao patrimônio cinematográfico universal. 
Tive a felicidade e a emoção de ver esta extraordinária película no Festival Cinematográfico de Cannes. Lembro-me muito bem da estrondosa manifestação tributada ao filme e à jovem Tatiana, pelo público tão diverso presente naquela noite. Tatiana não resistiu a emoção e duas lágrimas indiscretas misturaram-se ao seu sorriso. Durante as três semanas que passou em Cannes conquistou a admiração dos jornalistas e críticos representando ali a imprensa mundial. Serguei Urussevski, diretor de fotografia de «Quando Voam as Cegonhas» e «O Quadragésimo Primeiro», também lá estava com a sua enorme simpatia e simplicidade. $\mathrm{Na}$ noite de encerramento quando Tatiana, depois de receber o seu prêmio, saudou os presentes com um «C'est si bon. Ho-la-la!» foi acolhida com palmas estrondosas e entusiásticas.

O cinema de Mikail Kalatozov e as imagens de Serguei Urussevski têm as dimensões das obras clássicas, revivendo as melhores tradições dos mestres russos na surpreendente montagem. Porém, o filme de Kalatosov tem além do brilho exterior uma bela história sentimental (um apanhado palpitante da realidade soviética num passado ainda recente) do teatrólogo Victor Rozov. A simplicidade do tema casa-se perfeitamente com o virtuosismo formal, que dá as imagens um poder descritivo maior que o dos diálogos. «Quando Voam as Cegonhas» conta uma história de amor vivida por dois jovens - Boris (Alexel Batalov) e Verônica (Tatiana Samóilova), Os namorados passeiam despreocupadamente na madrugada de Moscou, beijam-se, abraçam-se, fazem planos para o futuro. Sobrevém a guerra e os namorados se separam - Boris vai para a frente, Verônica permanece em Moscou. As notícias escasseiam e as privações aumentam. Verônica é assediada por um primo de Boris (A. Chvorine), os bombardeios de Moscou obrigam à mudança para a Sibéria. A moça espera cada dia notícias de Boris, vivendo um pesadelo onde a ansiedade, a poesia e a brutalidade se mesclam.

A câmera de Urussevski realiza prodígios de dinamismo para captar o drama interior de Verônica. O operador segue-a no meio da multidão, numa louca corrida para a tentativa de suicídio ou quando está a sós com o primo de Boris durante um bombardeio. A 
fragilidade, a beleza, a angústia, a cólera, o cansaço, a elevação de Verônica, traduzem-se no rosto singelo da grande atriz soviética em magnífica sucessão de planos. Kalatosov soube mostrar de maneira lírica a descoberta do amor deste casal de adolescentes, com dramaticidade a tragédia da separação, com angústia, a infidelidade e a desilusão. O roteiro de Rozov, no entanto, exprime com calor, de maneira emocionante mesmo, a confiança naquilo que há de mais puro no ser humano: a razão, a inteligência e o amor. Quando voam as cegonhas é desses raros filmes em que o comovente sentimentalismo se traduz num raio de esperança, num poético raio de luz a iluminar o futuro.

Não deixem de ver «Quando voam as cegonhas», um filme generoso, belo e tocante, uma obra de excepcional valor plástico e cinematográfico que a «Palma de Ouro» do Festival de Cannes premiou há dois anos atrás ${ }^{41}$.

O correspondente sabe que muitos já viram o filme e há questões que não podem mais ser deixadas de lado. $\mathrm{O}$ cinema soviético se abrira novamente para a introspecção, para os sentimentos, medos e interesses individuais dos personagens. $O$ individual paira sobre o que antes era a primazia das necessidades coletivas e do espírito coletivista dos heróis típicos do realismo socialista estritamente imposto por Zhdanov. Sentimento antes do dever cívico. A forma, antes tão criticada, aflora e conduz a linguagem para experimentalismos poéticos.

As películas caem em mãos dos cineclubistas e ganham espaço nas associações de trabalhadores e de estudantes e sindicados, como se pode encontrar nas notas do jornal: Quando voam as cegonhas foi exibido pelo Cineclube da Liga da Mocidade Trabalhista, no auditório da $\mathrm{ABI}^{42}$. Uma das notas mostra a reabilitação e a abertura para a estética antes considerada formalista e anti-proletária dos mestres do cinema soviético dos anos 1920: "O GEC da UME exibirá hoje às 20 horas, no Ministério da Educação, QUANDO VOAM AS CEGONHAS, outra fita soviética do diretor Kalalázov, dentro do mesmo estilo ensinado pelos mestres Eisenstein, Pudovkin e outros" ${ }^{\prime 3}$. Pudovkin é até associado à estética que teve que

\footnotetext{
${ }^{41}$ Novos rumos, p.6. 1-7/7/1960.

${ }^{42}$ Novos rumos, p.6,16-22/6/1961.

${ }^{43}$ Novos rumos, p.6, 23-29/6/1961.
} 
abandonar no decorrer da década de 1930 em virtude das pressões dos defensores do realismo socialista.

Em meados de 1960 a reaproximação com a URSS e a campanha pelo reatamento das relações possibilitou a promoção de exibições públicas dos filmes antes proibidos oficialmente. Surgiu assim a União Cultural Brasil-URSS. Seu comitê de Cinema estava ainda em organização, ao contrário de outros ${ }^{44}$. No ano seguinte foi realizado o Festival soviético no MAM do RJ. De cinquenta filmes liberados pela Gosfilm, Itamaraty e Cinemateca Brasileira de São Paulo, apenas um trata da Segunda Guerra, sendo realizado durante sua vigência ( $O$ arco-íris, 1943, de Mark Donskoi $^{45}$. No ano seguinte, uma feira promovida pela URSS apresentou não apenas filmes, como mercadorias e tecnologia do país para o público brasileiro. Recebeu a matéria de capa: "Meio milhão de pessoas visitou exposição da URSS: primeira semana". A reportagem da Semana do Cinema Soviético Moderno em São Paulo e no Rio de Janeiro ganhou ilustrações. As sessões corridas arrecadaram dinheiro para a conservação dos filmes da Cinemateca. Recebeu incentivos da embaixada soviética, da Sovexportfilm e do Itamarati (uma das atrizes da delegação soviética, Ninel Mychkova, conseguiria imigrar para o Brasil em1962).

Os sete filmes a serem apresentados darão ao público uma visão mais completa e coerente da moderna cinematografia soviética já que só tivemos até agora exemplos raros e esparsos, tais como Quando voam as cegonhas e A balada do soldado. A Semana constará de filmes de autores já consagrados e de autores jovens que contribuíram para a renovação temática e estilística do cinema soviético ${ }^{46}$.

Quanta mudança a dos editores dos jornais do PCB! Passaram da compreensão e o julgamento da obra cinematográfica de uma história real a ser contada exatamente, como o ideal zhdanovista, para o de uma obra de arte, mantendo outras relações com a realidade que não a de puro reflexo, como defendia a nova safra de diretores soviéticos emergidos com o desgelo da desestalinização.

Assim, teremos A carta que não foi escrita, de Kalatozov, cujo nome está ligado a aceitação mundial no novo cinema soviético, já que a sua primeira grande

\footnotetext{
${ }^{44}$ Novos rumos, p.5, 15-21/7/1960.

${ }^{45}$ Novos rumos, p.5, 17-23/11/1961.

${ }^{46}$ Novos rumos, p.5, 11-17/5/1962.
} 
fita, Quando voam as cegonhas, mereceu a Palma de Ouro no Festival de Cannes de 1958. A carta apresenta uma característica rara no cinema soviético: seu pessimismo, que foi estranhado até pela crítica soviética. De um outro diretor jovem, Chukrai, do qual já vimos o romântico Quadragésimo primeiro, teremos Céu limpo ${ }^{47}$.

No entanto, a sinopse de Céu limpo, 1961, do diretor Grigori Chukhrai, não só repete a fórmula usada para Quando voam as cegonhas como vai além. O jornal expressa que "essa fita trata de um problema particularmente grave nos nossos dias e com que e defrontam todos os países mais adiantados: o da desigualdade entre o nível atingido pelas pesquisas científicas e pelas técnicas e a vida cotidiana ${ }^{48}$.

No fim de 1961 o jornal Novos rumos já havia publicado os principais documentos do XXII Congresso do PCUS, no qual Kruschev aprofundara e tornara mundialmente público o antistalinismo ${ }^{49}$, o que culminaria com a retirada de sua múmia do Mausoléu de Lenin e subsequente enterro sob as muralhas do Kremlin. A dessacralização de Stalin não atingira a sinopse dos filmes. Céu Limpo, ou Chistoe nebo, traz sim "um problema particularmente grave" naqueles dias: o do papel de Stalin e, consequentemente, a revisão da Grande Guerra Patriótica. A jovem Sacha perde o pai na guerra, sem poder vê-lo pela última vez devido à ineficiência burocrática na logística das tropas. Se enamora pelo condecorado piloto Aleksei, que retorna ao fronte. Enquanto vê os irmãos lutarem pela divisão do apartamento numa komunalka para suas famílias recém-constituídas, reencontra-se com um Aleksei caído em desgraça por ter sido obrigado a trabalhar num aeródromo nazista após ter seu caça abatido. Este, porém, é justiçado com a reabilitação e, a sisuda estátua de Stalin cede lugar no ecrã a um desgelo literal e torrencial. A segunda parte da sinopse constitui um ótimo malabarismo. A película de Chukhrai ganhou o Segundo Festival Internacional de Moscou sem que fosse noticiada ou o prêmio mencionado na sinopse, ao contrário de $O$ destino de um homem, ou Sudba Cheloveka, 1959, de Sergei Bondarchuk. Este também recebeu uma sinopse mutilada, silenciando o trabalho de Sokolov nos campos de trabalho forçado mantidos pelos nazistas, num momento em que a União Soviética

\footnotetext{
${ }^{47}$ Novos rumos, p.5, 11-17/5/1962.

${ }^{48}$ Novos rumos, p.5, 11-17/5/1962.

${ }^{49}$ Novos rumos, 15-21/12/1961.
} 
enfrentava a questão da reabilitação ou não daqueles considerados colaboradores, o que constituía ou não colaboração com os invasores.

Se o cinema soviético - em especial o cinema bélico - havia sido escondido ou atenuado pelos editores, em decorrência de seu conteúdo crítico e revisionista, a partir de 1962 ele torna-se elemento privilegiado da consolidação dos renovadores-revisionistas e em seu ataque contra os stalinistas-ortodoxos ${ }^{50}$. Fazem questão de ressaltar o caráter inovador da cinematografia soviética, como no título "Festival do novo cinema soviético: Festival História do Cinema Russo e Soviético". Uma exibição com vários recentes, entre eles os bélicos "Céu limpo, A paz seja contigo [Mir vkhodyashchemu, 1961], de Alexandr Alov e Vladimir Naumov, filme que recebeu o Prêmio Especial do Juri, um leão de ouro, no XXII Festival Cinematográfico de Veneza" ${ }^{\text {. O }} \mathrm{O}$ mesmo ocorre na reportagem "Cinema polonês de hoje em minas", sobre o Festival Cinema Polonês Hoje, do Centro de Estudos Cinematográficos de Minas Gerais. Entre outros filmes, foi apresentado o bélico Cinzas e diamantes, 1958, de Andrzej Wajda ${ }^{52}$.

A ofensiva pela revisão do conceito de arte e da história do partido e da URSS continua com a publicação do artigo "A arte da grande verdade", do ator Nicolai Tcherkassov, "o Ivã, o Terrível, o Otello, o Don Quixote", por ter representado estes papéis no cinema soviético (de Eisenstein e Kozintsev). Artigo originalmente publicado no Pravda (13-1-63).

Minha geração de atores teve a sorte de viver a época do apogeu do mais desbragado formalismo. Como isto soa hoje estranho! Mas nos começos da década de 20 difundiam-se seriamente os apelos dos formalistas extremados a acabarem com o Teatro de Arte, em torno dele colocar... metralhadoras.

Por que negá-lo? Muitos de nós, jovens, partilhávamos então os lemas de pseudo-inovação dos formalistas e em nossas pesquisas criadoras considerávamos necessário chegar à cena com a cabeça - tanto em sentido literal como figurado.

\footnotetext{
${ }^{50} \mathrm{O}$ grupo pró-Kruschev dá assim vazão ao discurso do novo secretário-geral, que assim se referiu ao cinema stalinista: "Tomemos, por exemplo, os nossos filmes históricos e militares e algumas criações literárias: eles nos fazem sentir doentes. Seu verdadeiro objetivo é a propagação do tema de louvor à Stalin como um gênio militar" (LAWTON, Anna (org.). The Red screen: politics, society, art in Soviet cinema. Londres: Routledge, 1992.p.5-6).

${ }^{51}$ Novos rumos, p.7, 25-31/5/1962.

${ }^{52}$ Novos rumos, p.5, 16-22/11/1962.
} 
Que dano irreparável acarretaria à arte cênica russa se triunfasse no teatro essa insensata palhaçada que subtraia a arte da verdade da vida, da luta pelas grandes ideias [...].

Hoje, observo com satisfação: no curso dos últimos vinte e poucos anos essa distância foi superada. Em nossos teatros formaram-se valorosos conjuntos artísticos dotados de grande maestria e talento multiformes. Aí manifesta-se claramente a influência benéfica de Stanislavski no teatro soviético ${ }^{53}$.

Vinte anos antes de 1963 coincide exatamente com a morte de Stalin. O formalismo criticado é o formalismo do próprio realismo socialista! E não o rotulado formalismo de Eisenstein, Vertov, Kuleshov, Pudovkin, Dovzhenko e outros, criticado durante o stalinismo. Textos de Eisenstein (e mesmo Um dia na vida de Ivan Denisovich, 1962, de Aleksandr Solzhenitsyn) são publicados no fim da sessão de cultura. O cinema crítico volta à cena com o artigo de Grigori Chukhrai "O problema da personalidade na arte". O novo cinema soviético é exibido não como uma epifania da superioridade soviética, mas sim como profundamente influenciado pelo neo-realismo italiano e a nouvelle vague francesa.

Nas películas dos neo-realistas italianos transluzem um vivo sentimento humano e uma profunda meditação sobre a vida do povo. Os neo-realistas não procuravam os heróis cinematográficos nos palácios e nos salões, mas nas ruas das cidades, nos bairros operários, nos campos. A pobreza e a miséria de seus protagonistas contrapunham a pureza de suas almas. A arte neorealista italiana se revelava contra as injustiças sociais e exaltava, ao mesmo tempo, a beleza do homem, de seu corpo, de seus sentimentos. Os protagonistas dos filmes neo-realistas sonham em realizar nobres ações. Talvez o mais belo naquelas películas fosse o sadio amor humano nelas refletido [...].

- Não existe o heroísmo? - perguntei eu. Ai está Raymonde Dien, que se estendeu sobre os trilhos para impedir a passagem de um trem carregado de armas, e ai estão os manifestantes que, sem temor aos riscos, saíram em defesa de seus direitos.

- Mas que garantia há de que realmente tinham razão? Talvez não devessem agir assim, contestou Chabrol.

${ }^{53}$ Novos rumos, p.5, 25-31/1/1963. 
- Isso é outra coisa, muito diferente - aleguei. A dúvida sobre a justeza da ação do herói não exclui a existência do próprio heroísmo. Eu participei na guerra e vi heroísmo autêntico e autênticos heróis. A eles deve o mundo hoje a sua existência. Sua memória é sagrada para mim $[\ldots]$.

$\mathrm{O}$ essencial na obra de arte não recai na autenticidade dos fatos por si mesmos. O espectador crê na veracidade de Romeu e Julieta, independemente de ter o seu criador tomado o tema da realidade ou do mundo de sua fantasia. O essencial da obra artística e de sua veracidade reside no que expressa o $\operatorname{artista}^{54}$.

Apesar de criticar o anti-heroismo de Claude Chabroi, Chukhrai não constrói qualquer personagem que lembre os heroicos e suicidas soldados russos do zhdanovismo. Alyosha derrota o panzer mais por acaso do que por ação consciente, em Ballada o soldate. O diretor tece louvores ao realismo italiano e seus principais expoentes, sobre como o cinema pode ser crítico e desvelar a realidade apenas com imagens e montagens. Faz a crítica ao capitalismo por ser um mundo no qual o indivíduo não se vê como parte de uma sociedade, onde impera o egoísmo e os interesses escusos, assim, tem ampla vasão. As pessoas abandonam uma vida consciente, ativa e engajada pela luta pelos pequenos interesses e desejos cotidianos. Uma questão sistêmica fortalecida pelos interesses de Estado. Em seguida, fala de seu Céu limpo - e, os mesmos problemas anteriormente citados como elementos do capitalismo aparecem no mundo socialista!

A película Céu limpo narra também a tragédia de um homem que conheceu a felicidade de ser cidadão e dela foi despojado devido a cruel e estúpida desconfiança que imperou em nosso país no período do culto à personalidade.

A tragédia do culto à personalidade reside na desarmonia nas relações entre o indivíduo e a coletividade. Junto com a coletividade, como intérprete de sua vontade e de seus anseios e como agente que adquire consciência, modela e cristaliza a experiência e o desejo da coletividade em forma de noções e ideias, o indivíduo conquista uma imensa força criadora. $\mathrm{O}$ homem desligado da sociedade, que se acha a margem dela ou quer por meio da força quer dominá-la, é causa da desventura de muitos e de sua própria desgraça.

${ }^{54}$ Novos rumos, p.5, 8-14/3/1963. 
Não obstante, enquanto a tragédia da pretensa "liberdade individual" é uma chaga da sociedade burguesa, que nasce de seu regime social, a tragédia do culto à personalidade não é mais que um episódio do desenvolvimento histórico de nosso país. $\mathrm{O}$ culto à personalidade é estranho ao socialismo. As causas a que obedece não podem ser buscadas nas peculiaridades do regime, mas em condições históricas concretas. Por sua fé sagrada no comunismo, ao qual ofereciam as melhores forças de sua alma e com o qual vinculavam seus mais nobres anseios, os comunistas soviéticos podiam supor, com pleno fundamento, que o homem que se achava a frente de sua luta era mais reto e mais desinteressado ainda que eles mesmos. Por acreditar em cada uma de suas palavras, ignorávamos então que o monopólio sobre a verdade leva a mentira. $\mathrm{O}$ culto à personalidade repercutiu gravemente na vida espiritual do país, em particular na cinematografia. Sob o peso das normas e exigências dogmáticas daquele período, o cinema soviético, o cinema de $O$ encouraçado Potemkin, de Chapaiev e O grande cidadão, foi perdendo suas qualidades inovadoras e, mais tarde, em certa medida, até suas qualidades ideológicas.

Após o XX Congresso do Partido, iniciou-se um período de ressurgimento do cinema soviético. Voltaram a aparecer películas exaltando o homem simples, seu mundo interior e sua luta heroica. Filmes como $O$ destino de um homem, Quando voam as cegonhas, Altura, A batalha no caminho, Serioja, Meu amigo Nicolau, Canção do berço, Nove dias de um ano, A infância de Ivan e muitos outros são testemunho do humanismo de nossa sociedade e de seu vigor espiritual $[\ldots]^{55}$.

Chukhrai concebe uma fórmula adequada aos novos tempos na URSS: um meio termo entre as necessidades do indivíduo e as da coletividade, que permita a liberdade artística mas que não seja niilista ou esotérico. Em sua crítica à ortodoxia stalinista, faz eco para a despolitização do partido, submergido pelo personalismo. Tema recorrente nos anos 1960.

${ }^{55}$ Novos rumos, p.5, 8-14/3/1963. 
[Sobre A infância de Ivan] A propósito desse método, que causou admiração a muitos críticos do Ocidente, recordo com orgulho e calor a poética e viril película $A$ infância de Ivan, do jovem diretor de cinema soviético Andrei Tarkovski, laureado com o Grande Prêmio do último festival cinematográfico de Veneza. A infância de Ivan nos relata a vida de um menino perdido no torvelinho da Segunda Guerra Mundial, de um menino que foi despojado de sua infância....

[...] Esse filme é concebido em dois planos: num plano real, onde se trava uma feroz e dolorosa luta, e no mundo dos sonhos, onde há fragmentos da invocação de uma infância remota, arrebatada e destruída. Já seu procedimento pressupõe uma grande bobagem ideológica, e talvez por isso influi tão profundamente e fortemente sobre o espectador. Os protagonistas da película não se entendem, não lhes causa angustia ter a consciência de sua própria insignificância. Sua consciência está limpa e clara. A lama da guerra não os converteu em animais. Pelo contrário, a consciência do dever ante os homens embeleza e faz palpitar sua vida. $\mathrm{Na}$ terrível situação da guerra, em meio à ruinas, ao ódio e a morte, vemos o homem, vigoroso e sem perder seu encanto humano, vemos, diria eu, a grandeza do homem. Conhecem o preço do amor e da amizade. Sabem bem o que é o heroísmo, mas não como substância filosófica. Não falam sobre o heroísmo, e sim vivem como os heróis ${ }^{56}$.

O "viver como heróis" não significa morrer com o brado de $\mathrm{Za}$ Rodinu! Za Stalina! (Pela Pátria-mãe, por Stalin). Nem mesmo pelo partido, que, no discurso kruchevista, vinha ocupando qualquer elemento positivo de Stalin, como as decisões na cúpula que levaram o país à vitória. O heroísmo é social, não partidário e ideológico, ou "filosófico".

Há pouco, em Roma, alguns artistas soviéticos discutimos em mesa-redonda com figuras da cultura italiana. Durante o encontro, o grande artista italiano Pasolini [...], elogiou minhas películas e os versos do poeta Ievtuchenko, porém fez a ressalva de que nossa arte é demasiado ingênua ou, como se manifestou ele, "não tem sentido trágico".

${ }^{56}$ Novos rumos, p.5, 8-14/3/1963. 
Condenou-nos por essa "falta de sentido trágico". Discordei dessa opinião, e disse que minhas três películas, tanto pela forma como pelo conteúdo, eram autênticas tragédias. $O$ quadragésimo primeiro apresentei a tragédia do amor da jovem guerrilheira Mariutka por um oficial "branco", cujo desenlace é o tiro fatal disparado por Mariutka nas costas de seu amado. Em A balada do soldado falo da morte de um rapaz simples e nobre, que podia ter sido um bom filho, esposo e cidadão, que podia ter construído ou embelezado a terra com jardins, mas que só teve tempo para ser soltado. Em Céu limpo, narro a tragédia de um cidadão despojado injustamente de sua honra ${ }^{57}$.

A reação de Chukhrai às críticas italianas mostra o quanto o cinema soviético havia abandonado o isolacionismo imposto pela zhdanovichina aos mais diferentes aspectos da vida do outro lado da Cortina de Ferro. Agora se integrara às novas correntes cinematográficas, recebendo influências externas, realizando assimilações e contribuições.
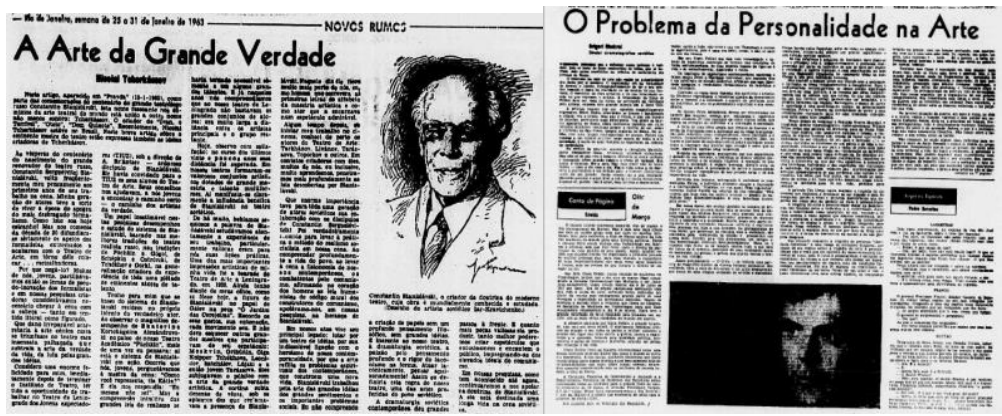

Figura 2 - Entrevistas com Tcherkassov e Chukhrai em Novos Rumos. Fonte:

Novos rumos, p.5, 25-31/1/1963; Novos rumos, p.5, 8-14/3/1963.

Na edição seguinte, o artigo "A polêmica na URSS sobre o realismo socialista" foi escrito por Augusto Pancaldi, correspondente em Moscou do jornal comunista italiano Rinascita. Procura-se um meio termo na arte, de forma a não se abandonar toda e qualquer preocupação social, ou inclusive adotar a postura dos artistas do mundo capitalista, e a liberar das amarras da ortodoxia. A luta contra o academicismo poderia ocultar a desorientação do artista que copia o Ocidente e introduz no país uma cultura estranha. Assim, acadêmicos, renovadores e imitadores ocidentais se engalfinham em cartas a

${ }^{57}$ Novos rumos, p.7, 8-14/3/1963. 
Kruschev para justificar sua postura e pedir ações contra seus concorrentes, mesmo o retorno a antiga ortodoxia ou a imposição do novo e o sacrifício do velho.

Efetuar uma distinção entre aqueles jovens que conscientemente escolheram o abstracionismo como arma polêmica contra o naturalismo pletórico da "velha guarda" acadêmica e aqueles que resvalaram na tentativa de imitar o Ocidente. [...].

A poesia, a música, o romance e sobretudo o cinema e a arquitetura produziram na URSS, neste último ano, obras originais, nas quais a pesquisa do novo não estava limitada a si mesma mas penetrava em uma batalha crítica, de caráter político e cultural, simultaneamente, contra as fórmulas congeladas do dogmatismo stalinista ${ }^{58}$.

Com a desagregação do bloco socialista caminhando a passos largos, desde a social-democratização dos PCs da Europa Ocidental até o cisma sino-soviético, os sinais dos editores se aproximam decisivamente dos reformadores e se afastam dos stalinistas dentro ou fora do Brasil. A representação da Grande Guerra Patriótica havia mudado. Ganhou contornos menos heroicos e políticos, mais baseados em preocupações e sentimentos individuais. Mais humana - e alinhada com o discurso liberalizante e reformista. No entanto, elementos nucleares foram poupados nas páginas do jornal - ao contrário da tela de cinema. Por mais que a imagem de Stalin e da arte soviética nos anos anteriores ao Desgelo tenha sido atacada e desmontada, a corrosão da visão do papel da URSS e dos comunistas na guerra presente nas películas soviéticas foi sistematicamente atenuada ou ignorada. O próprio antistalinismo foi suavizado nos primeiros anos de Novos rumos, apesar da derrota da ortodoxia ainda em 1958.A vitória sobre os nazistas foi o mais importante fator de crescimento dos partidos comunistas mundo afora no imediato pós-guerra. O PCB recebeu sua melhor votação nas eleições de 1945. Desfazer essa imagem não condizia com a estratégia positiva de legalização, que previa o crescimento do número de afiliados. Nem com os temores de novas fraturas e defecções, como o sectarismo após 1947 que afastou Mário e Carlos Drummond de Andrade, ou em 1956, com a debandada, entre outros, de Jorge Amado.

${ }^{58}$ Novos Rumos, p.5, 15-21/3/1963. 
Recebido em novembro de 2015. Aprovado em dezembro de 2015. 